\title{
IMPLICATIONS OF THE NEW RULE AgAinst PENALTIES
}

\author{
Jessica Palmer*
}

Whether a contractual term is penal and therefore unenforceable has usually been determined by distinguishing it from stipulations that are a reasonable contemplation of loss resulting from breach. This article considers recent decisions of the High Court of Australia and the United Kingdom Supreme Court that have made significant revisions of the rule. Both Courts have diverged from the traditional formulation and, to some extent, from each other. I argue that the traditional rule against penalties reflects foundational principles of contract law and not merely notions of fairness or justice in the round. The recent revisions to the rule have implications for the role and boundaries of contract law more generally and reflect increasing attention being paid to the "performance interest".

\section{INTRODUCTION}

It has long been accepted that stipulated remedies within contracts will be unenforceable if penal. The rule against penalties has been the subject of much controversy. It is seen by many as an unjustifiable limit on the freedom of parties to contract on their own terms and judges have for a long time remarked on the difficulty of identifying an underlying principle. ${ }^{1}$ For almost a century, whether a clause is penal has been determined by distinguishing it from a liquidated damages clause, that is, a sum that amounts to a reasonable estimate at the time of contract formation of loss likely to result from breach. ${ }^{2}$ Three recent decisions, of the High Court of Australia ${ }^{3}$ and the United

* Associate Professor, University of Otago. I am grateful to Sam Cathro for his helpful research assistance and to participants of the Private Law Roundtable for debating some of the important points herein with me. All errors and heresies are of course my own.

1 Astley $v$ Weldon (1801) 2 Bos \& Pul 346 at 350 at 350, 126 ER 1318 (Comm Pleas) at 1321 per Lord Eldon; Wallis v Smith (1882) 21 Ch D 243 at 256 per Sir George Jessell MR; and Robophone Facilities Ltd v Blank [1966] 1 WLR 1428 (CA) at 1446 per Diplock LJ as cited in Cavendish Square Holding BV v El Makdessi [2015] 3 WLR 1373 (SC) at [3] per Lord Neuberger and Lord Sumption.

2 Dunlop Pneumatic Tyre Co Ltd v New Garage and Motor Co Ltd [1915] AC 79 (HL).

3 Andrews v Australia and New Zealand Banking Group Ltd [2012] HCA 30, (2012) 247 CLR 205; and Paciocco v Australia and New Zealand Banking Group Ltd [2016] HCA 28 [Paciocco (HCA)]. 
Kingdom Supreme Court, ${ }^{4}$ have, however, made modifications to the rule that diverge both from the traditional formulation and from each other in significant respects. ${ }^{5}$

This article considers these changes and the implications that they have for the penalty doctrine and, importantly, for the law of contract more generally. It begins by discussing the conventional understanding of the rule against penalties and the changes made to the rule by the recent cases. I will then suggest a justification for the rule against penalties in light of which the new modifications can be evaluated. In my opinion, the penalty doctrine has traditionally been tied to notions of loss and compensation because this reflects the fundamental means of enforcement used by the courts when a party breaches. I argue that the underlying concern of the rule against penalties is that parties' stipulated remedies cannot extend beyond the courts' own limits, otherwise the institution of contracting itself is threatened by the loss of the courts' ability to supervise and enforce the bargain. The move away from compensation to focus on the innocent party's legitimate interest in the performance of the contract represents a significant development in the penalty doctrine but one that is consistent with wider fundamental features of contract law. If, however, the performance interest is to replace compensation as the relevant comparator, it must be understood to be qualified so that only interests which a court could normally condone and enforce can justify a stipulated remedy.

\section{THE TRADITIONAL UNDERSTANDING OF THE RULE AGAINST PENALTIES}

The modern rule against penalties has usually consisted of a ritual incantation of Lord Dunedin's guidelines in Dunlop Pneumatic Tyre Co Ltd v New Garage and Motor Co Ltd (Dunlop). ${ }^{6}$ The case concerned a contract for the supply of tyres that required of the buyer that the tyres must not be onsold for less than the specified prices and that a sum of $£ 5$ per tyre was payable for every tyre sold in breach of the stipulation. The fine was held not to be a penalty because although it might have seemed at first sight to be an excessive amount, it was included in the contract in order to prevent "a system of injurious undercutting" likely to cause damage to the seller that would be impossible to estimate. ${ }^{7}$ The amount of the charge was not incommensurate with that objective.

Lord Dunedin contrasted penalties with liquidated damages describing the latter as "a genuine covenanted pre-estimate of damage" and the former as "a payment of money stipulated as in terrorem of the offending party". ${ }^{8}$ Noting that the question was one of construction of the particular

4 Cavendish, above n 1.

5 Litigation that includes the question of penalties will be heard by the New Zealand Court of Appeal later this year, although it concerns the law of New South Wales rather than that of New Zealand: Torchlight Fund No 1 LP (in rec) v Johnstone [2015] NZHC 2559. Dunlop, above n 2 .

7 At 92 per Lord Atkinson.

8 At 86 . 
contract, Lord Dunedin listed four tests that "may prove helpful, or even conclusive": ${ }^{9}$ first, a sum that is extravagant or unconscionable when compared to the greatest loss likely to be proved from breach is a penalty; secondly, where the breach is a failure to pay, a sum that is greater than the amount that was originally required to be paid will be a penalty; thirdly, a sum that is required to be paid in response to several different breaches that cause differing extents of damage is a penalty; and finally, a sum is not automatically a penalty simply because precise pre-estimation is not possible.

Over time, the application of the penalty rule extended to other agreed remedies beyond stipulations to make payment, including withholding payment clauses and forced transfer clauses. ${ }^{10}$ However, the Dunlop guidelines continued to be employed and the emphasis remained on contrasting the value and effect of the stipulated remedy with what would otherwise have been the remedy available to the aggrieved party.

\section{RECENT MODIFICATIONS TO THE RULE}

\section{A United Kingdom}

In 2015, the Supreme Court gave judgment on two appeals heard together concerning the penalty doctrine, Cavendish Square Holding BV v El Makdessi (Cavendish) and ParkingEye Ltd v Beavis (ParkingEye). ${ }^{11}$ The facts of each were very different. In Cavendish, a contract for the sale of a majority shareholding provided for the contract price to be paid by instalments and included a significant premium for goodwill of approximately USD 114,000,000. The goodwill was protected by means of restrictive trade covenants on the seller who had been instrumental in the company's success. In the event of breach, the purchaser could withhold payment of two of the instalments and exercise an option to buy the seller's remaining shareholding at net asset value excluding any goodwill component. The seller breached the covenants and sought to avoid enforcement of the terms on the basis that they were penalties. In ParkingEye, a user of a public carpark challenged the $£ 85$ fee for staying beyond the two-hour parking time limit as a penalty. ${ }^{12}$

The important revision made by the Supreme Court to the rule against penalties related to the appropriate standard or test for identifying a penalty. The primacy of the compensation principle in Lord Dunedin's formulation has been criticised as too restrictive. It does not recognise instances

9 At 87.

10 Jobson v Johnson [1989] 1 WLR 1026 (CA); Amaltal Corp Ltd v Maruha (NZ) Corp Ltd [2004] 2 NZLR 614 (CA); and Ringrow Pty Ltd v BP Australia Pty Ltd [2005] HCA 71, (2005) 224 CLR 656.

11 Cavendish, above n 1.

12 The case garnered significant public attention with the user of the carpark in ParkingEye having funded the litigation through the use of crowd funding. He had initially needed approximately $£ 1,000$ but attracted pledges amounting to $£ 80,000$. 
where a remedial clause is employed for a legitimate commercial purpose other than simply to avoid financial loss, such as to protect a party's reputation. Dissatisfaction with both compensation and deterrence as the appropriate standards by which to identify penalties was clearly noted by Lord Neuberger and Lord Sumption: ${ }^{13}$

The real question when a contractual provision is challenged as a penalty is whether it is penal, not whether it is a pre-estimate of loss. These are not natural opposites or mutually exclusive categories. A damages clause may be neither or both. The fact that the clause is not a pre-estimate of loss does not therefore, at any rate without more, mean that it is penal. To describe it as a deterrent (or, to use the Latin equivalent, in terrorem) does not add anything. A deterrent provision in a contract is simply one species of provision designed to influence the conduct of the party potentially affected. It is no different in this respect from a contractual inducement. Neither is it inherently penal or contrary to the policy of the law.

The rule was said to be concerned with protecting parties from unconscionable or extravagant terms. But identifying unconscionability requires some standard or norm against which a term is to be judged. The Court replaced the yardstick of compensation with the notion of a legitimate interest in performance of the relevant primary obligation. The tests proposed in the multiple judgments are all consistent on this point, although worded slightly differently. ${ }^{14}$ Lord Neuberger and Lord Sumption, with whom Lord Clarke and Lord Carnwarth concurred, described the test as: ${ }^{15}$

... whether the impugned provision is a secondary obligation which imposes a detriment on the contract-breaker out of all proportion to any legitimate interest of the innocent party in the enforcement of the primary obligation. The innocent party can have no proper interest in simply punishing the defaulter. His interest is in performance or in some appropriate alternative to performance.

The Dunlop test was not itself overturned but relegated to circumstances where the relevant agreed remedy is a stipulation to pay a sum of money. ${ }^{16}$ Indeed, the outcome in Dunlop is consistent with this approach. The interest being protected by the $£ 5$ charge per tyre was "the maintenance of a system of trade, which only functions if all trading partners adhere to it". ${ }^{17}$ The charge was not itself intended to be an accurate estimation of financial loss.

Their Lordships' application of the law to the facts in Cavendish and ParkingEye highlighted some difficult issues. The Court was unanimous that the clauses in both cases were not penal, but

13 At [31], Lord Clarke, Lord Carnwarth and Lord Hodge concurring.

14 At [152] per Lord Mance, Lord Clarke and Lord Toulson concurring, and [255] per Lord Hodge, Lord Clarke and Lord Toulson concurring.

15 At [32], Lord Clarke and Lord Carnwarth concurring.

16 At [32] and [255].

17 At [152]. 
the reasons given varied. There was disagreement on whether the particular clauses at issue were properly regarded as remedial or primary.

In the Cavendish appeal, Lord Neuberger, Lord Sumption and Lord Carnwarth held that both the provision allowing the purchaser to withhold payment and the forced buyout were price adjustment clauses that were central to the contract. Where the seller failed to provide goodwill, by contravening the trade restraint, the contract provided that the buyer would pay less and the working relationship would be severed by virtue of the buy-out clause. Both clauses were not contractual alternatives to damages and did not prevent a claim for damages. Instead, they were part of the primary obligations of the parties and could not be subjected to the rule against penalties. ${ }^{18}$ The remaining Law Lords were ambivalent as to the classification of the withholding payment clause but ruled it was not a penalty given the buyer's legitimate interest in protecting the goodwill value. ${ }^{19}$ Lord Hodge and Lord Clarke, however, viewed the buy-out clause as a secondary obligation but one that was not unconscionable in the context of the agreement as a whole. Ongoing cooperation and goodwill were both important components of the original price and it was conceivable that their demise would materially reduce the value of the business. ${ }^{20}$

In the ParkingEye appeal, the Court emphasised the legitimate interest the carpark owner had in providing free parking to attract customers that required a regular turnover of carparks and an ability for the carpark operator to cover its costs of operating and monitoring the carpark. ${ }^{21}$ The charge for parking beyond the authorised time limit was not unconscionable or extravagant given the objective the carpark owner was trying to achieve and comparing the charge to that imposed by other carpark providers. $^{22}$

\section{B Australia}

Class action over common bank fees have provided the context for the High Court of Australia to reconsider the penalty rule. Two decisions of the High Court of Australia have resulted. The first concerned the reach of the penalties doctrine; the second concerned the test for penalty.

In Andrews $v$ Australia and New Zealand Banking Group Ltd (Andrews), decided three years before Cavendish, the Court was asked to determine whether bank fees applicable where a borrower exceeded approved limits were penal. ${ }^{23}$ The same question had been raised in an earlier decision of

18 At [74], [80] and [81]. In any event, both clauses were justified by the purchaser's legitimate interest in measuring price by the value of the business being bought: at [75] and [82].

19 At [181] per Lord Mance and [278] per Lord Hodge.

20 At [280]-[282] per Lord Hodge.

21 At [98] per Lord Neuberger and Lord Sumption.

22 At [193]-[199] per Lord Mance and [284]-[288] per Lord Hodge.

23 Andrews, above n 3. 
the High Court of England and Wales, Office of Fair Trading v Abbey National Plc, where Andrew Smith J ruled that no breach was committed by a borrower who exceeded authorised limits. ${ }^{24}$ The relevant fees were not triggered by breach and therefore were not secondary remedial obligations capable of being subjected to the rule.

The Court in Andrews emphasised the early equitable history of the rule in bonds cases to justify its position that there is an equitable form of the penalty doctrine which can apply to secondary obligations that arise as a result of failure, not just a breach, of a primary obligation. ${ }^{25}$ The penalty doctrine extends to "collateral" clauses that impose an additional detriment upon the "failure of the primary stipulation". ${ }^{26}$ In addition, the equitable jurisdiction enables remedial flexibility such that courts can award partial relief, unlike in the common law doctrine:27

If compensation can be made to the second party for the prejudice suffered by failure of the primary stipulation, the collateral stipulation and the penalty are enforced only to the extent of that compensation. The first party is relieved to that degree from liability to satisfy the collateral stipulation.

Evident in this remark is the clear contrast between compensation and penalty adopted by Lord Dunedin in Dunlop. An agreed remedy cannot give disproportionately more than compensation for the loss suffered and the striking down of an agreed remedy cannot deprive the innocent party of compensation altogether. Reference to the award as partial enforcement of the penalty clause is unhelpful. It is really the Court fulfilling its supervisory role by imposing its own secondary obligation on the defaulting party to pay compensation. Indeed, there is little difference in practical outcome between this equitable version of penalty and the common law rule given that, when a damages clause is struck down, the innocent party retains a right to seek damages for compensation at law. ${ }^{28}$

In Cavendish, the United Kingdom Supreme Court rejected the Australian extension of the penalty rule to collateral obligations in Andrews. ${ }^{29}$ The High Court of Australia's historical analysis

24 Office of Fair Trading v Abbey National plc [2008] EWHC 875, [2008] 2 All ER 625 (Comm).

25 Andrews, above n 3, at [45].

26 At [10] per French CJ, Gummow, Crennan, Kiefel and Bell JJ, and at [45].

27 At [10].

28 United Dominions Trust (Commercial) Ltd v Ennis [1968] 1 QB 54, [1967] 2 All ER 345; Scandinavian Trading Tanker Co v Flota Petrolera Ecuatoriana [1983] 2 AC 694 (HL); AMEV-UDC Finance Ltd v Austin (1986) 162 CLR 170 (HL); and Workers Trust \& Merchant Bank Ltd v Dojap Investments Ltd [1993] AC 573 (PC).

29 Cavendish, above n 1, at [241] per Lord Hodge and [130] per Lord Mance. 
was doubted and, more significantly, the approach was considered to be inconsistent with the court's limited jurisdiction to regulate only remedies for breach. ${ }^{30}$

The second relevant decision of the High Court of Australia was handed down in July of this year. Paciocco $v$ Australia and New Zealand Banking Group (Paciocco) concerned the enforceability of late payment fees on credit card accounts. ${ }^{31}$ The case did not specifically engage the first question of ambit. It was accepted by the bank that the relevant clause was triggered by breach. Nevertheless, the Court affirmed its earlier ruling in Andrews in the face of the Supreme Court's criticism of it in Cavendish. French CJ's short judgment emphasised that Australia had its own common law ${ }^{32}$ and Gageler $\mathrm{J}$ defended the historical analysis undertaken in Andrews. ${ }^{33}$

However, as to the separate question of the test for penalty, the High Court of Australia adopted substantively the same approach as that of Cavendish. Emphasising that the rule against penalties should not unduly encroach upon freedom of contract, ${ }^{34}$ the majority held that a clause is not penal if it protects the legitimate interest of the party seeking to rely on the clause. Both Kiefel J, with whom French CJ concurred, and Keane $\mathbf{J}$ referred to a stipulated sum as being acceptable where it is commensurate with the relevant interests of the party in whose favour the stipulation was made. ${ }^{35}$ In Nettle J's dissenting judgment, his Honour did not reject this approach altogether but rather held that it was only necessary to depart from the Dunlop test when the resulting damage is incapable of quantification such that a comparison with compensation is not possible. ${ }^{36}$

On the facts, the bank admitted the late payment fee was not determined by any pre-estimate of ordinarily recoverable damages and sought to justify the fee on an ex post facto consideration of costs it had incurred. These costs, it said, extended beyond direct operational costs flowing from breach, to include loss provisioning ${ }^{37}$ and increases in regulatory costs. The majority accepted that late payment fees were included in the contract to protect the bank's legitimate interest in receiving timely repayments from its customers and that late payment adversely impacted upon the bank's

30 At [42].

31 Paciocco (HCA), above n 3.

32 At [6]-[10].

33 At [118]-[127],

34 At [156] per Gageler J and [220]-[221] per Keane J. See also [342] per Nettle J in dissent.

35 At [52] per Kiefel J and [269]-[270] per Keane J. See also [164]-[166] per Gageler J.

36 At [317]-[321].

37 That is the diminution in value of debts held by the bank (as choses in action) attributable to the increased potential for non-recovery of the debt. 
interest in the ways claimed. ${ }^{38}$ The late payment fee was not grossly disproportionate to these combined costs and thus not a penalty. ${ }^{39}$

Despite the broad ambit of the penalty doctrine in Australia to clauses beyond remedies for breach, the legitimate interest comparator approach sets a high threshold for establishing a penalty given that most stipulated remedies can be justified in some way or other by the interests of the enforcing party. For that reason, it is suggested that clauses declared to be penal will be rather few and far between in both Australia and the United Kingdom. ${ }^{40}$

\section{Two Different Rules?}

In summary, the High Court of Australia and the United Kingdom Supreme Court have adopted two different approaches to the ambit of the rule against penalties. In the United Kingdom, only obligations that take effect on breach engage the rule against penalties. In Australia, a secondary or collateral obligation may be the subject of attention if it is triggered either by breach or failure of a primary condition. The Australian approach widens the reach of the penalty doctrine and grants remedial discretion to the court, neither of which is attractive to those who regularly draft contracts. ${ }^{41}$ On the question of the standard by which a clause is to be adjudged penal, however, there appears to be little divergence.

Both Courts judge the clause against the interest of the party seeking to enforce the clause. Parties are allowed to stipulate remedies for reasons other than the provision of a pre-estimated loss. This approach enables greater freedom ${ }^{42}$ and probably increased confidence for contracting parties given that clauses that may once have fallen foul of the penalties doctrine will survive, it appears, so

38 At [58]-[68] per Kiefel J and [171]-[176] per Gageler J.

39 Keane $\mathbf{J}$ also reasoned that the bank's interest in lending profitably necessitated a fee for late payment because late payment increases a bank's risk and therefore inhibits its ability to maximize its revenues by reducing costs and attracting more customers: at [277]-[278]. This overtly economic analysis should be treated cautiously. Its effect would seem to be that any stipulated payment for breach could never be a penalty because breach will usually always be an economically inefficient outcome for the innocent party, thus justifying that party's use of a stipulated sum to discourage or remedy the inefficiency. If that is the case, there is no rule against penalties.

40 Katy Barnett "Coralling the penalties horse: Paciocco v Australia and New Zealand Banking Group Ltd" (8 August 2016) Melbourne Law School: Opinions on High, High Court Blog 〈www.blogs.unimelb.edu.au>.

41 See for example practitioner commentaries: Tracey Petter "Supreme Court unshackles the rule on penalties" (16 November 2015) Dentons <www.dentons.com>; Julian Acratopulo "Landmark Supreme Court Decision - The Penalties Doctrine Lives On (In a New Guise)" (4 November 2015) Clifford Chance <www.cliffordchance.com>; Rachel Chaplin "Liquidated damages and the law on penalties" (11 November 2015) Clyde\&Co <www.clydeco.com>; and Elizabeth Macknay, Matthew Keogh and Tim Goyder "Penalties and protecting legitimate interests: differences between the United Kingdom and Australia" (23 November 2015) Herbert Smith Freehills <www.herbertsmithfrehills.com>.

42 Lord David Hope "The Law on Penalties - A Wasted Opportunity?" (2016) 33 JCL 93. 
long as there is a reasonable explanation for their presence. Certainly, the application of the revised approach by both Courts to the particular clauses before them suggests as much. In order to evaluate these revisions made to the penalty rule, it is necessary to provide some explanation of the underlying concern that the law is seeking either to correct or to protect by the rule.

\section{A JUSTIFICATION FOR THE TRADITIONAL APPROACH: UPHOLDING THE COURT'S REMEDIAL JURISDICTION}

In my opinion, the penalty doctrine is best understood as a necessary protection of the court's remedial jurisdiction in order that contracts remain legally enforceable. The focus on a comparison between the stipulated clause and the compensation that would otherwise be available was justified because it preserved the court's absolute jurisdiction to enforce contracts by providing that breaches be compensated. ${ }^{43}$

This justification can be explained in the following way. In the absence of any established ground for setting aside contracts, ${ }^{44}$ parties are assumed to have freely entered into and freely given undertakings to each other. It is the law of contract that renders those obligations legally enforceable and it is the role of the court to effect enforcement. Enforceability is a key attribute of a contract; it distinguishes contracts from mere social agreements. However, the means of enforcement that the common law uses are indirect. It does not enforce performance of the parties' agreed undertakings themselves, known as primary obligations. Instead, it recognises or imposes secondary obligations that require the defendant to remedy breach of his or her primary obligations by compensating for any harm suffered from failure to perform the primary obligations. ${ }^{45}$ Thus, a basic principle of contract law is that where a party breaches, he or she will not usually be ordered to perform but to compensate the other party for any loss suffered. ${ }^{46}$ At common law, the default rule is compensation. ${ }^{47}$ We say that he or she is under a secondary obligation to make good any loss arising from breach of the primary obligation. These secondary obligations are the domain of the court. Were one party permitted to stipulate that the other is obliged to pay damages which are

43 Cavendish, above n 1, at [42]; Paciocco v Australia and New Zealand Banking Group Ltd [2014] FCA 35, [2015] FCAFC 50 [Paciocco (FCFCA)] at [25] per Allsop CJ; and Torchlight Fund, above n 5, at [83].

44 Such doctrines include undue influence, duress, unconscionable bargains, and mistake.

45 Photo Production Ltd v Securicor Transport Ltd [1980] AC 827 (HL) at 848-849 per Lord Diplock. This is in contrast to equity where enforcement of the primary obligation is readily available: see $P \& O$ Nedlloyd BV v Arab Metals Co [2007] 2 Lloyd's Rep 231 (CA) at [47] per Moore-Bick LJ. Equity follows the common law and so will not respond to a breach of contract with a performance remedy unless there is an additional factor that would demand a remedy beyond that available at common law, such as where damages are inadequate.

46 Trey Qualls "Take a Second-Look at Liquidated Damages in Texas" (2015) 67 Baylor L Rev 666 at 674.

47 Exports Credits Guarantee Dept v Universal Oil Products Co [1983] 1 WLR 399 (HL) at 403 per Lord Roskill. 
excessive in comparison with what a court would or could award, the term would place a court called upon to enforce it in a position of inherent contradiction.

The rule against penalties is thus consistent with two key values of the common law of contract: first, parties to a contract are generally free to determine for themselves the content of the primary obligations they will accept; ${ }^{48}$ and, secondly, courts will usually enforce primary contractual obligations only indirectly by imposing secondary remedial obligations. The presumptive remedy (or secondary obligation) for breach of contract is compensation for loss arising.

As to the first value, there are, of course, examples within the law where parties' freedom to determine their own primary obligations is limited. Terms may be implied contrary to the parties' own intention, such as terms implied into contracts for the sale of goods. ${ }^{49}$ Likewise, terms may be excluded by statute despite the parties' apparent agreement. The recent enactment of an unfair contract terms regime in New Zealand is an example of this ${ }^{50}$ For the most part, these restrictions belong in the legislative domain where they are deemed necessary by Parliament in order to give effect to a competing public policy or value and can be carefully prescribed. Contract law does recognise the ability of courts to imply terms in fact but there has been much controversy in recent years regarding the precise approach to be taken to implication. ${ }^{51}$ There is a general acceptance that terms are not to be too easily implied and the New Zealand courts have shown recently a hesitancy to depart from the parties' existing terms and the ordinary meaning thereof unless there is a clear gap in the written terms that must be filled. ${ }^{52}$ Likewise, there is no general liberty on the part of the courts to ignore parties' express terms.

The second value mentioned above, that courts enforce contracts indirectly by the secondary obligation of compensation for loss resulting from breach, explains why despite a reticence to disturb parties' primary obligations, courts will entertain challenges to secondary or remedial obligations stipulated in the contract. Secondary obligations are the means used by the law of contract to enforce contractual obligations. Without this means of enforcement, contract law would be rendered impotent. The relevance of the court's supervisory role to the penalty doctrine was

48 Cavendish, above n 1, at [73].

49 Sale of Goods Act 1908; and Consumer Guarantees Act 1993.

50 Fair Trading Act 1986, s 26A.

51 Attorney General of Belize v Belize Telecom Ltd [2009] 1 WLR 1988 (PC); Sembcorp Marine Ltd v PPL Holdings Pte Ltd [2013] SGCA 43, [2013] 4 SLR 193; Arnold v Britton [2015] UKSC 36; and Marks and Spencer plc v BNP Paribas Securities Services Trust Company (Jersey) Ltd [2015] 3 WLR 1843 (SC).

52 Satterthwaite v Gough Holdings Ltd [2015] NZCA 130 at [67] (leave to appeal refused by the Supreme Court in Gough v Gough Holdings Ltd [2015] NZSC 115); and Firm PI 1 Ltd v Zurich Australian Insurance Ltd \& Body Corp 398983 [2014] NZSC 147, [2015] 1 NZLR 432. 
recognised by the Supreme Court in Cavendish in its refusal to extend the doctrine beyond remedial terms. As Lord Neuberger and Lord Sumption said: ${ }^{53}$

Modern contracts contain a very great variety of contingent obligations. Many of them are contingent on the way the parties choose to perform the contract ... The potential assimilation of all of these to clauses imposing penal remedies for breach of contract would represent the expansion of the courts' supervisory jurisdiction into a new territory of uncertain boundaries, which has hitherto been treated as wholly governed by mutual agreement.

An objection can be raised at this point that because the law of contract allows parties to agree to their own remedies and, indeed, such clauses are common practice it cannot be solely the court's remit to determine the parties' secondary obligations to compensate. Indeed, some argue that the principle of freedom of contract demands otherwise. ${ }^{54}$ However, the presence of such clauses does not mean that the law is allowing the parties to usurp the court's enforcement role. Rather, agreed remedies are permitted because they are (and only so long as they are) a helpful proxy for the court's determination of the compensation payable. This is really just a concession to efficiency. Agreed remedies save significant time and cost for both the court and the parties at the point of breach and promote certainty, so long as they are consistent with (and do not usurp) the court's remedial jurisdiction. ${ }^{55}$ It is thus clear that agreed remedies must be limited by the compensation principle otherwise the court's enforcement role is jeopardised and the institution of contracting is consequently placed in doubt. The rule against penalties is the means by which the court can enforce the compensation principle in the face of parties' attempts to determine their secondary obligations for themselves. ${ }^{56}$

The law's tolerance of limitation and exclusion clauses does not undermine this reasoning. Penalty clauses threaten the courts' ability to enforce contracts because they overcompensate the innocent party, something that the law of contract does not allow a court to do. ${ }^{57}$ The court cannot impose a secondary obligation to overcompensate and thus it cannot logically enforce the term. Limitation and exclusion clauses, on the other hand, are usually employed by contracting parties in

53 Cavendish, above n 1, at [42].

54 Lord Hope, above n 42.

55 Francis Dawson "Determining Penalties as a Matter of Construction" [2016] LMCLQ 207 at 218; and Qualls, above n 46, at 672.

56 Indeed, that the plaintiff can claim damages for breach where an agreed remedies clause is unenforceable as a penalty is further support for the argument presented here that the underlying concern is to give effect to the compensation principle: see the cases cited above $n 28$.

57 Bloxham v Robinson (1996) 7 TCLR 122 (CA); C\&P Haulage v Middleton [1983] 3 All ER 94 (CA); and Omak Maritime Ltd v Mamola Challenger Shipping Co [2010] EWHC 2026, [2011] 1 Lloyd's Rep 47 (QB). 
order to undercompensate for loss. The assumption by a party of a lesser secondary obligation does not present the same threat to the court's enforcement role.

The compensation principle has been a key feature of contract law that limits freedom of contract to the extent that parties cannot attempt to require greater secondary obligations than the court will impose.

Thus, the link between compensation and penalty is essential to the supervisory role of the court. Lord Dunedin's identification of penalties by a comparative exercise with compensation was therefore justified. Yet, the compensation comparator is only relevant so long as the relief available at law for breach of contract is limited to compensation. Were punitive damages to become available for breach of contract, for example, a penalty clause may no longer be inconsistent with the courts' jurisdiction. ${ }^{58}$ Contract law in New Zealand does not punish parties in breach of their primary obligations. ${ }^{59}$ Hence, where parties stipulate a remedy that does in fact punish, it cannot be enforceable by the court and so it must be rejected as an inappropriate proxy for the court's determination of remedy. However, as will be discussed further herein, it may be that the scope of the compensation principle within contract law is expanding as the courts show a greater willingness to consider the particular interests bargained for by the relevant parties themselves, often referred to as their performance interest or legitimate interest. Some clauses that once would have been considered penal may no longer be so because a broader view is taken of the parties' interests and therefore of loss. This does not necessarily mean that the Dunlop test is wrong, but rather that the likely damage for which compensation would be available and to which the stipulated remedy must be compared has changed.

It is then necessary to consider whether the modifications made to the Dunlop test in Andrews and Cavendish are coherent within the remedial jurisdiction justification proffered here or whether they suggest that a different justification and a significantly different rule should be adopted in New Zealand. I turn now to offer some critical reflections on the Australian and English modifications to the penalty doctrine from a New Zealand perspective.

58 The requirement that the stipulated term must not be extravagant or disproportionate would remain but the relevant comparator would not be the loss likely to be recoverable, but the exemplary damages likely to be recoverable. This, again, emphasises that the court's enforcement role cannot be ousted by the parties whatever the remedies available to the court.

59 Paper Reclaim Ltd v Aotearoa International Ltd [2006] 3 NZLR 188 (CA). 


\section{IMPLICATIONS OF THE NEW RULES}

\section{A The Ambit of the Rule}

\section{Secondary obligations and the breach limitation}

The High Court of Australia's rejection of the breach limitation on the penalty doctrine has come under significant criticism from both academics ${ }^{60}$ and judges. ${ }^{61}$ Whether or not the Court's historical analysis was correct, equity's aversion to penalty clauses has long since been absorbed into the common law. Equity follows the law and does not usurp the common law's jurisdiction unless there can be demonstrated some lacuna or inequity in the operation of the common law. Yet, it is not difficult to justify the different treatment that remedial clauses responding to breach receive in the common law penalty rule such that there is no inequity arising.

As explained above, the distinction between primary obligations and secondary obligations arising upon breach is critical. Contract law maintains a healthy respect for the parties' autonomy to make bargains, both good and bad. For this reason, the power afforded to the court by the penalty doctrine to ignore particular terms of the contract should not extend to rewriting parties' primary obligations. However, a viable contract law requires that courts must be able to enforce contracts. Enforcement is achieved indirectly by the recognition of a secondary obligation to require a remedy (compensation) in the event of breach. Parties can attempt to incorporate a secondary obligation into the contract at the time of entering into their primary obligations for the sake of efficiency and certainty, but courts must retain the ability to review and set aside secondary obligations that overreach the compensation principle and thus usurp the courts' authority. Breach of a primary obligation is a necessary prerequisite of a secondary obligation and therefore a necessary requirement before the rule against penalties can apply. The rule against penalties must be limited to secondary obligations arising in the event of breach because, by definition, this is the only way that a secondary obligation comes into existence.

Removing the breach limitation as the High Court of Australia has done extends the court's jurisdiction to interfere with not only secondary obligations, properly so called, but with a range of other clauses seen to be collateral to the main agreement. Apart from the practical difficulty of deciphering which clauses are collateral, the approach is a significant intrusion into party autonomy without an accompanying clarity as to the justification of the intrusion. If the reasons are to do with some broader notion of correcting unconscionability or oppression, as will be discussed further

60 JW Carter and others "Contractual Penalties: Resurrecting the Equitable Jurisdiction" (2013) 30 JCL 99; Edwin Peel "The Rule Against Penalties" (2013) 129 LQR 152; and Sirko Harder "The Scope of the Rule Against Contractual Penalties: A New Divergence" in Andrew Robertson and Michael Tilbury (eds) Divergences in Private Law (Hart Publishing, Oxford, 2016) 135.

61 Cavendish, above n 1, per Lord Neuberger and Lord Sumption. 
below, it is difficult to see why the rule stops at collateral obligations. The current Australian approach is, with respect, an odd sort of halfway house that cannot be explained coherently.

\section{Classifying primary and secondary obligations}

The tension that exists between primary and secondary obligations can be explained as the result of balancing freedom of contract with the compensation principle. The parties are at liberty to determine their primary obligations but the court will interfere to prohibit one party from punishing the other when breach occurs. Yet while as a matter of principle, the distinction so important to the penalty rule between primary and secondary obligations may be clear, the classification of a term as a matter of fact as either primary or secondary can seem arbitrary at times. With skilful drafting, remedial clauses can be converted into primary obligations or conditional collateral obligations that are out of reach of the rule against penalties. ${ }^{62}$ For example, fees for late completion can be rewritten as discounts for early completion and withholding payment clauses can be drafted as price adjustment clauses.

The problem of evasion of the rule by clever drafting is probably not resolvable and it would create huge uncertainty and transactional expense if all contractual clauses could be subjected to the scrutiny of the court. ${ }^{63}$ Some commentators have suggested that the distinction between primary and secondary obligations is so arbitrary that the alternative approach of abandoning the rule against penalties altogether is to be preferred. ${ }^{64}$ It has also been noted that the increasing legislative protection from unfair terms and the other established protective doctrines in the common law of contract (such as lack of notice, duress and undue influence) mean that there is no need for the continued application of a rule against penalties. However, arguments in Cavendish that the rule should be abolished or restricted were not met with enthusiasm by the Supreme Court and are unlikely to be successful in New Zealand either. ${ }^{65}$ If, as has been argued here, the concern of the rule against penalties is to ensure the court retains an ability to enforce contracts, it is different from, rather than made redundant by, other doctrines and rules that apply to protect weaker parties from unfair terms.

62 Sarah Worthington "Common Law Values: The Role of Party Autonomy in Private Law" in Andrew Robertson and Michael Tilbury (eds) The Common Law of Obligations: Divergence and Unity (Hart Publishing, Oxford, 2016) 301 at 316

63 Bobby Lindsay "Penalty Clauses in the Supreme Court: A Legitimately Interesting Decision?" (2016) 20 Edin LR 204 at 207; and Martin Hogg "Some further thoughts on the penalty clause rule in the Supreme Court" (16 March 2016) Obligations Law Blog <www.obligations.law.ed.ac.uk>.

64 Peel, above n 60, at 156; Edwin Peel "Unjustified Penalties or an Unjustified Rule Against Penalties? (2014) 130 LQR 365; Worthington, above n 62 at 322; and James C Fisher "Rearticulating the Rules Against Penalty Clauses" [2016] LMCLQ 169 at 171.

65 See for example Cavendish, above n 1, at [162]-[270] per Lord Mance, and [256] and [261] per Lord Hodge. 
Indeed, the distinction between primary and secondary obligations may not be too difficult to draw. As Lord Mance suggested in Cavendish:66

... in most cases parties know and reflect in their contracts a real distinction, legal and psychological,

between what, on the one hand, a party can permissibly do and what, on the other hand, constitutes a

breach and may attract a liability to damages for - or even to an injunction to restrain - the breach.

The parties' drafting will not necessarily be determinative. The judgments in Cavendish on this point show that classifying the clause is a question of construction over which judges may reasonably disagree. ${ }^{67}$ It may also be that the two enquiries contained in the penalties rule are not exclusive of each other: asking whether the clause meets the substantive test for a penalty may reveal whether the clause is a primary or secondary obligation. This is particularly so if the Dunlop test is used.

\section{B The Test for Penalties}

\section{The role of unconscionability and good faith}

In contrast to the remedial jurisdiction justification advocated in this article, some commentators consider that the penalty doctrine is concerned with requiring good faith and fairness in contractual relations. ${ }^{68}$ In the same vein, some courts have emphasised that the penalties doctrine is only engaged where the clause can be said to be oppressive or unconscionable. ${ }^{69}$ In Elsley v JG Collins Insurance Agencies Ltd Dickson J in the Supreme Court of Canada said: ${ }^{70}$

It is now evident that the power to strike down a penalty clause is a blatant interference with freedom of contract and is designed for the sole purpose of providing relief against oppression for the party having to pay the stipulated sum. It has no place where there is no oppression.

The New Zealand Court of Appeal relied on this passage in Amaltal Corporation Ltd v Maruha (NZ) Corporation $\mathrm{Ltd}^{71}$ when it rejected an argument that a forced transfer clause in a joint venture

66 At [130].

67 See above $\mathrm{n} 18$.

68 JW Carter and Elisabeth Peden "A Good Faith Perspective on Liquidated Damages" (2007) 23 JCL 157; and William Day "Penalty Clauses Revisited" [2014] JBL 512.

69 AMEV-UDC Finance Ltd, above n 28, at 193-194 per Mason and Wilson JJ; and Yarra Capital Group Pty Ltd v Sklash Pty Ltd [2006] VSCA 109.

70 Elsley v JG Collins Insurance Agencies Ltd [1978] 2 SCR 916 (SCC) at [47] cited with approval in Philips Hong Kong Ltd v Attorney General of Hong Kong (1993) 612 BLR 49 (PC) at 57-58.

71 Amaltal Corporation Ltd v Maruha (NZ) Corporation Ltd [2004] 2 NZLR 614 (CA). 
agreement was a penalty. ${ }^{72}$ In a judgment delivered by Blanchard $\mathrm{J}$, the Court noted as relevant that there was no appearance of actual or potential oppression in the agreement. ${ }^{73}$

Caution must be exercised when referring to notions of oppression, unconscionability, unfairness and lack of good faith as if they are absolute tests. These are abstract notions with no substantive objectively determined criteria of their own. If the doctrine were to be decided on the basis of these values alone, it would create significant uncertainty. ${ }^{74}$

It is a mistake to assume that unconscionability or any similar notion can serve adequately as the content of the rule. Some norm or standard is required by which the stipulated term can be evaluated to determine whether it is in fact oppressive or unconscionable and hence unenforceable. In most cases, proving oppression or inequality of bargaining power per se has not been a necessary or sufficient element of establishing a penalty. ${ }^{75}$ Instead, the focus has been on the comparison of the agreed remedy and likely loss to assess whether the agreed remedy is oppressive or unconscionable. Indeed, that is how Lord Dunedin referenced unconscionability in his formulation of the rule in Dunlop Tyres: ${ }^{76}$

... it will be held to be a penalty if the sum stipulated for is extravagant and unconscionable in amount

in comparison with the greatest loss that could conceivably be proved to have followed from the breach.

In this article I have suggested an explanation of the rule against penalties that operates to prevent parties from using agreed remedies to achieve overcompensation. Such provisions have the effect of punishing the breaching party. Because punishment is not a function of the law of contract, it would be unconscionable for the innocent party to rely on, and for the court to condone, a clause that extends disproportionately beyond compensating for harm suffered. Unconscionability in this context is judged by the standard of compensation. Of course, the court's conception of what is unconscionable may change over time. For example, it is conceivable (although in my opinion regrettable ${ }^{77}$ ) that punitive damages may one day be a permitted remedy for breach of contract. If that point is reached, it would be inappropriate to use compensation as the sole norm against which to evaluate parties' agreed remedies. But in any event, what will be unconscionable must be assessed

72 The case primarily concerned whether the rule against penalties was a matter of "public policy" as provided for in Art 34 of the First Schedule to the Arbitration Act 1996 for the purpose of allowing an appeal against an arbitral award. The Court held it was not and, even if an appeal had been permitted, the clause was not a penalty.

73 Amaltal Corporation Ltd, above n 71, at [58]-[61].

74 Cavendish, above n 1, at [259] per Lord Hodge.

75 Torchlight Fund, above n 5, at [102]-[105].

76 Dunlop, above n 2, at 87 (emphasis added).

77 Ernest Weinrib "Punishment and Disgorgement as Contract Remedies" (2003) 78 Chic-Kent LR 55; and Allan Beever "The Structure of Aggravated and Exemplary Damages" (2003) 23 OJLS 87. 
by reference to the remedies ordinarily available to the court given that remedies are the means used by courts to enforce contracts. The significance of the Supreme Court's decision in Cavendish is the shift away from compensation as the criterion or norm against which unconscionability is assessed towards a performance-based interest.

My argument in this section has been simply to warn against any formulations of the rule against penalties that seek to invoke broad notions of oppression, extravagance, unconscionability and the like without application of some detailed criterion or more concrete norm.

\section{The increasing importance of the performance interest}

The clear view of both the United Kingdom Supreme Court and the High Court of Australia is that a clause should not be said to be penal merely because it amounts to more than the likely compensatory response to breach. Both Courts have held that the genuine pre-estimate of loss test is not fundamental to the penalty inquiry because it does not conclusively prove that the clause is or is not penal in the sense that one party is punishing the other. Instead, the appropriate norm is the legitimate interest of the innocent party in the enforcement ${ }^{78}$ or performance ${ }^{79}$ of the [primary] obligation. ${ }^{80}$ While compensation remains relevant, it "is not necessarily the only legitimate interest that the innocent party may have in the performance of the defaulter's primary obligations". ${ }^{81}$

In Cavendish, their Lordships opined that the Dunlop comparison with pre-estimated loss is normally appropriate for specified sum clauses because the parties' interest in such a clause will usually be to provide compensation for breach. ${ }^{82}$ But the loss comparator was not considered appropriate where parties are seeking to protect interests other than compensation. Lord Mance gave the following examples: ${ }^{83}$

The maintenance of a system of trade, which only functions if all trading partners adhere to it (the

Dunlop case), ... terms of settlement which provide on default for payment of costs which a party was

prepared to forego if the settlement was honoured (the Cine Bes case); likewise, also the revision of

financial terms to match circumstances disclosed or brought about by a breach: Lordsvale and other cases.

The notion that the performance interest is relevant to the penalty inquiry is not entirely new. In deciding the $£ 5$ charge was not a penalty in Dunlop, Lord Atkinson referred to the seller's object in

78 Cavendish, above n 1, at [31]-[32] per Lord Neuberger and Lord Sumption.

79 At [255] per Lord Hodge.

80 At [31]-[32] per Lord Neuberger and Lord Sumption

81 At [32] per Lord Neuberger and Lord Sumption, and [247] per Lord Hodge.

82 At [32] per Lord Neuberger and Lord Sumption, and [152] per Lord Mance.

83 At [152] per Lord Mance. 
making the agreement, finding that the charge was necessary to "to prevent the disorganisation of their trading system and the consequent injury to their trade". ${ }^{84}$ In Nettle J's dissenting judgment in Paciocco, his Honour also referred to the importance of the parties' underlying interest for which protection is being sought. However, rather than seeing this as something different from the compensation interest, his Honour viewed Lord Dunedin's compensation comparison as giving effect to the performance interest: ${ }^{85}$

... ordinarily the only legitimate interest of an innocent party in the performance of a primary obligation

is in its performance or in some appropriate alternative to performance. Hence, in the case of a

"straightforward damages clause" the innocent party's interest will rarely extend beyond compensation

for the breach and, therefore, in such a case, it is to be expected that the Dunlop tests will usually be

"perfectly adequate" to determine whether a provision is a penalty.

The weakness of an exclusively compensatory comparison to determine penalties could be said to be illustrated by the facts of the ParkingEye case. The carpark operator was not liable to suffer any direct loss as a result of overstaying motorists given that there was no charge to use the carpark. Nevertheless, several factors pointed to the carpark operator having a legitimate interest in charging overstaying motorists and the charge was not excessive given that interest. Both the carpark operator and the carpark owner had a legitimate interest in controlling access to the carpark to ensure customers could access the retail outlets which the carpark serviced, to encourage prompt turnover of car parking spaces, and to fund the cost of operating the carpark. All of these were achieved effectively by the overstay charge. ${ }^{86}$ The amount of the charge was not substantially higher than that charged by local authorities for car parks on public land and thus was not excessive or extravagant. ${ }^{87}$ Accordingly, the Court ruled unanimously that the charge was not a penalty.

In New Zealand, the performance interest has been explicitly recognised and incorporated into the law on contractual damages. ${ }^{88}$ This is, on the whole, a welcome development because it enables the courts to make a more accurate assessment of the innocent party's true loss. In Marlborough District Council $v$ Altimarloch Joint Venture Ltd (Altimarloch), ${ }^{89}$ the Supreme Court had to

84 Dunlop, above n 2, at 91-92.

85 Paciocco (HCA), above n 3, at [321] (citations omitted).

86 Cavendish, above n 1, at [99] per Lord Neuberger and Lord Sumption, [193] per Lord Mance, and [286] per Lord Hodge.

87 At [100] per Lord Neuberger and Lord Sumption, and at [287] per Lord Hodge.

88 Marlborough District Council v Altimarloch Joint Venture Ltd [2012] NZSC 11, [2012] 2 NZLR 726. The High Court of Australia has done likewise in Tabcorp Holdings Ltd v Bowen Investments Pty Ltd [2009] HCA 8, (2009) 236 CLR 272 at [12] referring to the promisee's legitimate interest in the performance of the breached term.

89 Altimarloch, above n 88. 
determine the appropriate compensation where a vendor of land had failed to provide promised water rights with the land. Access to water was of fundamental importance to the purchaser who had bought the land in order to establish a vineyard. The difference in value between land with and without the water rights was $\$ 400,000$ while the cost to cure the breach was just over $\$ 1,000,000$ made up of the price of some water rights available for sale from a third party and the cost of construction of a dam on the land to capture the remaining shortfall in water. The three substantive judgments, given by Blanchard and Tipping $\mathrm{JJ}$ in the majority and Elias $\mathrm{CJ}$ in dissent, all referred to the need to award the cost of cure in cases where diminution in value did not give effect to the innocent party's performance interest. ${ }^{90}$ Blanchard and Tipping JJ went so far as to recognise an alternative category of damages to compensation which they labelled, unsurprisingly, performance damages and which are available where the subject matter of the contract cannot be readily substituted in the market. ${ }^{91}$ The majority awarded cost of cure.

It is likely then that incorporation of the performance interest into the test for establishing penalties will be welcomed in New Zealand. Two notes of caution must be sounded, however. First, it is important that a party's performance interest is qualified by a requirement of legitimacy. If the rule against penalties is to remain coherent, the shift to focussing on performance interests must not be taken as free license by parties to include whatever remedies they might choose limited only by the requirement that they are not extravagant or exorbitant when compared with the overall purposes or objectives of their bargain. Rather, legitimate interests in performance should only be those that the court can recognise and for which it is able to provide relief. The reason parties cannot, for example, use agreed remedies to punish is ultimately because courts do not condone punishment for breach. ${ }^{92}$ A performance interest that extended to justifying exemplary damages would be illegitimate. On the other hand, following Altimarloch, in a contract where the subject matter is unique, parties could stipulate an estimated cost of cure as payable for breach. Likewise, a provision requiring the breaching party to disgorge profits made in breach could be permitted so long as the particular contract is sufficiently analogous to other contracts in which courts have previously permitted account of profits or disgorgement for breach. ${ }^{93} \mathrm{And}$, if the law of contract damages were to allow for punitive damages in the future, then it is entirely conceivable that a remedy stipulated by the parties could be intended to punish. The point is not that punishment is not allowed; but that

90 At [25] per Elias CJ, [67] per Blanchard J and [107] per Tipping J.

91 At [158] per Tipping J. In my opinion, these "performance damages" to award the cost of cure are really a form or measure of compensation damages where compensation is conceptualised more broadly than just direct or market loss.

92 Paper Reclaim Ltd v Aotearoa Int Ltd [2006] 3 NZLR 188 (CA).

93 Attorney-General v Blake [2001] 1 AC 268 (HL) where the House of Lords relied upon the plaintiff having a legitimate interest in preventing breach to justify an account of profits; Stevens v Premium Real Estate [2009] NZSC 15, [2009] 2 NZLR 384; and Denaro Ltd v Onyx Bar \& Cafe (Cambridge) Ltd HC Hamilton CIV 2010-419-777, 7 February 2011. 
parties cannot provide a remedy that is beyond what the court can enforce. Terms stipulating remedies must continue to be compared to the remedies that would be available from the courts to test whether they are penal or not.

In my view, to divorce the performance interest from available remedies risks confusing the parties' motivation for a clause with the function of a clause. It ought not to matter what reasons the party had for stipulating a particular secondary obligation, but simply whether the effect of that clause is a remedy contemplated by contract law. This is so for two reasons. First, the commercial, economic, or even moral reasons for which a party acts are not normally an enquiry the court makes or is equipped to make. That seems dangerously close to adjudication of parties' individual motivations which are not necessarily the subject of mutual agreement and not something of which the law of contract has traditionally taken note. Secondly, legitimate interests must be limited to those for which damages are recoverable "otherwise the prohibition on penalties would be illusory". 94

Hence, adapting the test of Lord Neuberger and Lord Sumption cited earlier, the enquiry should be along the following lines: a clause will be a penalty where it is a secondary obligation that imposes a detriment on the contract-breaker (which may include a requirement to pay or transfer property or to forgo receipt of money or property), where that detriment is out of all proportion to any legitimate interest of the innocent party in the performance of the primary obligation. Legitimate interests are only those in relation to which a court would be likely to grant relief.

The second note of caution to sound if the performance interest emphasis is adopted in New Zealand concerns the more practical issue of how the performance interest is to be identified; what evidence will be relevant to that question and to the subsequent inquiry of whether the stipulated clauses are excessive or exorbitant. The Supreme Court in Cavendish adopted a contextual approach, considering the wording of the clauses of the contract, and common practices that apply either in the relevant industry or to the type of transaction. Lord Neuberger and Lord Sumption referred to the purpose of a clause being "ordinarily an inference from its effect". .5

In New Zealand, construction is a broad contextual exercise that admits both pre-contractual negotiations and subsequent conduct where relevant, and places significant weight on the notion of (commercial) common sense. ${ }^{96}$ Although there are signs in very recent cases that something of a retreat from the contextual approach is occurring where the ordinary meaning of the words in the

94 Torchlight Fund, above n 5, at [189].

95 Cavendish, above n 1, at [28].

96 Vector Gas Ltd v Bay of Plenty Energy Ltd [2010] NZSC 5, [2010] 2 NZLR 444; and Gibbons Holdings Ltd $v$ Wholesale Distributors Ltd [2007] NZSC 37, [2008] 1 NZLR 277. 
written contract is plain, ${ }^{97}$ recourse to context and reliance on inferences will likely become common in penalty disputes given that the parties' interest in performance is not often the subject of express drafting in contracts. ${ }^{98}$ The notion of performance interest is somewhat ambiguous and reasonable judges will inevitably differ on its identification on the facts of cases before them and on the relevant costs or susceptible losses in relation to that interest. Indeed, in Paciocco, while the majority concerned themselves with the bank's legitimate interest in receiving the payment due at all, Nettle $\mathbf{J}$ analysed the interest as being the receipt of payment on time. For the majority, this meant that the adverse effects of non-payment, not just late payment, were relevant to assessing whether the fee was disproportionate to the interest.

When determining whether the particular clause is excessive or exorbitant, three further points are noted. First, their Lordships in Cavendish considered the circumstances of the parties to be important including the relative experience and sophistication of the parties; the respective bargaining strength of the parties; the presence of expert legal advice; and the extent of any negotiations. ${ }^{99}$ Inequality of bargaining power, surprisingly, did not appear to feature in the deliberations of the majority in Paciocco, despite the case concerning a standard-form contract between a large commercial bank and general consumers. ${ }^{100}$

Secondly, there is some uncertainty over whether evidence of actual loss sustained from breach can be relevant given that the question, whether a clause is penal, is to be decided at the time the contract was entered into. In the Full Court of the Federal Court in Paciocco, the Court had ruled any consideration of the resultant loss from breach irrelevant because such an approach was necessarily ex post facto both the formation and breach of the contract. ${ }^{101}$ The High Court of Australia had no such qualms. ${ }^{102}$ Lord Woolf in Philips Hong Kong Ltd v Attorney General of Hong Kong also admitted subsequent evidence. ${ }^{103}$

Thirdly, there is also conflicting authority on whether either party's subjective state of mind is relevant. Some cases suggest not, reasoning that a clause can still be a penalty even if the innocent

97 Firm PI 1 Ltd, above n 52; and New Zealand Carbon Farming Ltd v Mighty River Power Ltd [2015] NZCA 605 .

98 One of the effects of greater recognition of the performance interest in contract law may be more information being included in the written contract itself to pre-empt courts from implying their own view of the bargain. This will likely lessen the need for courts to look to context outside the contract to construe the performance interest.

99 Cavendish, above n 1, at [75] and [152].

100 But see Paciocco (HCA), above n 3, at [371] per Nettle J in dissent.

101 Paciocco (FCFCA), above n 43, at [116]-[117] per Allsop CJ.

102 Paciocco (HCA), above n 3, at [169] per Gageler J.

103 Philips Hong Kong Ltd v Attorney General of Hong Kong, above n 70, at 59. 
party thought it had a legitimate commercial justification for the clause; and likewise, the fact that the defaulting party may have readily agreed and not felt pressured by the term will not save it from being a penalty. ${ }^{104}$ Other cases have considered the parties' subjective understanding of the legitimacy of their purposes or interests as critical. ${ }^{105}$ However, the rule against penalties is not concerned with an allegation of any sort of fraud. There seems to be no good reason to depart from the standard objective approach to construction.

\section{CONCLUSION}

The rule against penalties should not be understood as concerned primarily with preventing unfairness or unconscionability generally. The purpose of the rule is to prevent parties overreaching the court's remedial jurisdiction. It is fundamental that the court's ability to enforce a contract is not undermined in order that the institution of contracting is not itself undermined. The focus of the test is therefore on secondary obligations triggered by breach of other terms and should not be extended to enable the courts to police the content of other obligations in the contract.

The test for penalties has until very recently required a comparison to likely recoverable loss. This is because common law courts have traditionally enforced contracts by requiring compensation for loss suffered. The intrusion on parties' autonomy that the rule against penalties has allowed was justified but only to the extent that it was concerned with achieving compensation for breach. The approach taken in Australia and the United Kingdom has recently shifted from a compensationbased inquiry to one focusing on legitimate interests in performance.

The performance interest is a helpful notion for identifying the true loss that results from breach but it must be applied cautiously. It should not be used to justify parties' use of stipulated remedies that exceed those available from the courts. To do so would jeopardise the court's crucial enforcement role. The performance interest is gaining significant traction in modern contract law but it raises important and difficult questions that need further detailed consideration. To what extent does the performance interest differ from the compensation principle? How is the performance interest to be identified in individual contracts? Are general principles of construction applicable or is a different enquiry needed ? $^{106}$ What evidence will be relevant? These enquiries lie beyond the scope of the present article.

104 Cavendish, above n 1, at [28]; and Campbell Discount Co Ltd v Bridge [1962] AC 600 (HL) at 622 per Lord Radcliffe.

105 See the cases discussed in Torchlight Fund, above n 5, at [110]-[117].

106 Dawson, above n 55, at 214. 